\title{
THE COMMON LAW OF WAR
}

\author{
JENS DAVID OHLIN*
}

\begin{abstract}
In recent litigation before U.S. federal courts, the government has argued that military commissions have jurisdiction to prosecute offenses against the "common law of war," which the government defines as a body of domestic offenses, such as inchoate conspiracy, that violate the American law of war. This Article challenges that definition by arguing that stray references to the term "common law of war" in historical materials meant something completely different. By examining the Lieber Code, the writings of early natural law theorists, and early American judicial decisions, this Article concludes that the "common law of war" referred to a branch of the law of nations that applied during internal armed conflicts, such as civil wars with non-state actors. This body of law was called "common," not because it was extended or elaborated by the common law method of judge-applied law, but rather because it was "common" to all mankind by virtue of natural law, and thus even applied to internal actors, such as rebel forces, who were not otherwise bound by international law as formal states were. By recapturing this lost definition of the common law of war, this Article casts some doubt on the U.S. government's position that military commissions have jurisdiction not only over international offenses, but also domestic violations of the law of war.
\end{abstract}

* Associate Dean for Academic Affairs \& Professor of Law, Cornell Law School, jdo43@ cornell.edu. I received helpful suggestions and comments from Gabriella Blum, Steve Vladeck, Marty Lederman, Kevin Clermont, John Dehn, Silja Vöneky, Elizabeth Anker, Sid Tarrow, Chelsea Gunter, Benedict Kingsbury, and colloquia participants at Harvard and Cornell. 


\section{TABLE OF CONTENTS}

INTRODUCTION . . . . . . . . . . . . . . . . . . . . . . . . . . . . . . 495

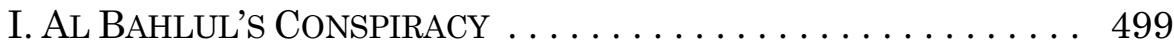

II. QUIRIN \& THE JURISPRUDENCE OF MISTAKES . . . . . . . . 503

III. THE LINCOLN ASSASSINATION . . . . . . . . . . . . . . . . . . . . . 509

IV. THE LIEBER CODE. . . . . . . . . . . . . . . . . . . . . . . . 513

V. The Natural LaW ERA. . . . . . . . . . . . . . . . . 519

VI. THE DUAL MEANING OF COMMON LAW . . . . . . . . . . . 523

VII. CONSPIRACY UNDER THE COMMON LAW OF WAR. . . . . . . . 529

CONCLUSION......................... 533 


\section{INTRODUCTION}

What is the "common law of war"? Good question. Few people truly know, even among experienced scholars of international humanitarian law or the law of armed conflict. This phrase sounds like a legal term with a technical meaning, but, as it happens, law of war experts with deep technical expertise have little familiarity with the concept. If the term has a settled meaning, it is a hidden one. So it came as a surprise when the United States government invoked the "common law of war" in recent litigation before the United States Court of Military Commission Review and the D.C. Circuit Court of Appeals in the case of Al Bahlul, an alleged member of al-Qaeda who was prosecuted for the substantive crime of conspiracy before a military commission. ${ }^{1}$ In the past, the U.S. government had asserted that conspiracy was an international law violation and therefore subject to prosecution before a military tribunal. ${ }^{2}$ However, after both academic experts and federal judges expressed grave skepticism that conspiracy was criminalized under

1. See United States v. Al Bahlul, 820 F. Supp. 2d 1141, 1167, 1183 (U.S.C.M.C.R. 2011), vacated, No. 11-1324, 2013 WL 297726 (D.C. Cir. Jan. 25, 2013), reh'g en banc granted, No. 11-324 (D.C. Cir. Apr. 23, 2013), aff'd in part, vacated in part, 767 F.3d 1 (D.C. Cir. 2014), vacated in part, 792 F.3d 1 (D.C. Cir. 2015).

2. A four-judge plurality in Hamdan v. Rumsfeld (Hamdan I) concluded that conspiracy was not a violation of international law. See 548 U.S. 557, 563 (2006). However, Justice Kennedy, who provided the fifth vote in favor of Hamdan, did not sign on to that portion of the opinion and resolved the case on other grounds. Id. at 636-54 (Kennedy, J., concurring). Consequently, the fate of conspiracy under international law was left to the lower courts to resolve. Originally, the U.S. Court of Military Commission Review held that conspiracy was triable at a military commission as a violation of international law. See Al Bahlul, $820 \mathrm{~F}$. Supp. 2 d at 1224 ("[C]onspiracy as defined in the 2006 M.C.A. $\S 950 v(b)(28)$ and the 2007 M.M.C. clearly casts a wide net of potential individual criminal liability; however, we are mindful that two Congresses and two Presidents have agreed that conspiracy to commit offenses enumerated in the 2006 and 2009 M.C.A. violate the law of armed conflict and are punishable by military commission."). The Court of Military Commission Review viewed the conspiracy charge as supported by international law because it was essentially similar to the criminal organization charges in the Nuremberg Charter. See id. at 1209; see also Jonathan A. Bush, The Prehistory of Corporations and Conspiracy in International Criminal Law: What Nuremberg Really Said, 109 Colum. L. Rev. 1094, 1160-62 (2009). However, that court's opinion was plagued by confusion between conspiracy as a substantive offense and conspiracy as a mode of liability, demonstrated in the court's analysis of Joint Criminal Enterprise liability applied at the ad hoc tribunals, including at the International Criminal Tribunal for Yugoslavia. See Al Bahlul, 820 F. Supp. 2d at 1210-13. 
international law, the U.S. government finally conceded that conspiracy was illegal under American law but not international law. ${ }^{3}$ One would think that this concession would doom conspiracy prosecutions before the military commissions, but not so. Instead, the federal government broadened its theory of the commissions' jurisdiction. Instead of limiting themselves to the international law of war offenses, government attorneys alleged that military commissions also had jurisdiction to try violations of the "common law of war," defined as "the practice of our own military authorities before the adoption of the Constitution, and during the Mexican and Civil Wars," 4 a position that had previously been advocated in 2006 by Justice Thomas in his lengthy dissent in Hamdan. ${ }^{5}$

This change in position was greeted with shock. ${ }^{6}$ What is the common law of war, and what precisely is common about it? ${ }^{7}$ Common as in common law from Britain? Or common law as in judge-made precedent? Or neither? The U.S. government was relying on the fact that the phrase "common law of war" was used in passing in the Quirin decision in $1942,{ }^{8}$ and that therefore there

3. In the Hamdan II litigation before the D.C. Circuit after the Supreme Court's failure to resolve the conspiracy question, see Hamdan v. United States (Hamdan II), 696 F.3d 1238 (D.C. Cir. 2012), government lawyers eventually conceded that conspiracy was not an international law violation. See Al Bahlul, 767 F.3d at 38 (noting the government's own admissions over the course of the Hamdan II litigation that "the offenses of conspiracy, solicitation, and providing material support to terrorism have not attained international recognition at this time as offenses under customary international law" and that the government "conceded that [all three offenses] are not violations of the international law of war." (alteration in original) (internal citations omitted) (first quoting Brief for the United States at 57, Al Bahlul, 767 F.3d 1 (No. 11-1324), ECF No. 1374120, then quoting Transcript of Oral Argument at 15, A1 Bahlul, 767 F.3d 1 (No. 11-1324), ECF No. 1460836)).

4. Ex parte Quirin, 317 U.S. 1, 31 (1942) (footnotes omitted).

5. See Hamdan I, 548 U.S. at 689 (Thomas, J., dissenting) ("The common law of war as it pertains to offenses triable by military commission is derived from the 'experience of our wars' and our wartime tribunals, and 'the laws and usages of war as understood and practiced by the civilized nations of the world." (internal citations omitted) (first quoting W. WINTHROP, Military LaW and Precedents 839 (rev. 2d ed. 1920), then quoting Military Comm'ns, 11 Op. Atty. Gen. 297, 310 (1865))).

6. See, e.g., Geoffrey S. Corn et al., The War on Terror and the Laws of War 218 (2d ed. 2015).

7. See Jens David Ohlin, What Is the Common Law of War?, OpINIO JuRIs (July 28, 2014, 1:45 PM), http://opiniojuris.org/2014/07/28/common-law-war/ [https://perma.cc/G9PX-D4RU].

8. See Quirin, 317 U.S. at 34 ("[T] he specified violations are intended to be only illustrative of the applicable principles of the common law of war, and not an exclusive enumeration of the punishable acts recognized as such by that law."). 
was substantial precedent that military commissions have jurisdiction over common law offenses. ${ }^{9}$ This theory was rejected by a threejudge panel of the D.C. Circuit in Hamdan II, though the full D.C. Circuit may be more tempted by it. ${ }^{10}$

This Article is a story about a single legal term and its history. Despite what the government says, the phrase "common law of war" simply does not stand for the idea that there is a body of American law of war offenses that can be prosecuted before non-Article III tribunals. ${ }^{11}$ In fact, "common law of war" means something far different, though its meaning can only be understood by reference to a bygone era-the era when international law was defined primarily by natural law. ${ }^{12}$ And the term lends no support for the government's position that military commissions can prosecute conspiracy as a violation of the common law of war. This is a story of lost meaning, of concepts that fade away and are then rediscovered, plucked from history and placed out of context, in an attempt to sow confusion with ahistorical arguments.

The rest of this Article proceeds, out of necessity, in reverse chronological order. The reason for proceeding in reverse chronological order is to emphasize and appreciate the difficulty that modern jurists face when dealing with a legal concept with an uncertain

9. See Brief for the United States at 21, Al Bahlul, 767 F.3d 1 (No. 11-1324), ECF No. 1374120 ("The Quirin decision relied on military commission jurisdiction over spying, although spying is not a violation of international law, and in both Quirin and Hamdan I the Court looked to domestic precedents, rather than only considering international law, to determine whether an offense is lawfully triable by military commission.").

10. See Hamdan II, 696 F.3d 1238, 1252 (D.C. Cir. 2012) ("The Government contends that those Civil War precedents illuminate what it calls the 'U.S. common law of war'-not the international law of war. But the statutory constraint here imposed by 10 U.S.C. $\S 821$ is the international law of war."). The panel went on to note that the government's own filings in Quirin embellished the common law of war theory: "This 'common law of war' is a centuriesold body of largely unwritten rules and principles of international law which governs the behavior of both soldiers and civilians during time of war." See id. (quoting Brief for the United States at 29, Ex parte Quirin, 317 U.S. 1 (1942)).

11. For the best expression of the U.S. government's view, see Brief for the United States, supra note 9 , at 40 .

12. For further reflections on the role of natural law in the development of international legal discourse, see Harold Hongju Koh, Why Do Nations Obey International Law?, 106 YALE L.J. 2599, 2606-07 (1997) ("Thus, by the mid-seventeenth century, the theoretical foundations that came to govern traditional international law had been laid: The discipline was now deemed a branch of jurisprudence, born of both nature and of human will, driven by sovereignty concerns, and segmented into public and private components."); Jens David Ohlin, The Doctrine of Legitimate Defense, 91 InT'L L. STUd. 119, 121-40 (2015). 
pedigree. For any jurist, the most logical place to look for an answer is recent history-that is, the usage of the phrase in recent legal texts. That investigation might seem illuminating but the light gives false comfort. In tracing the phrase further back in time, what is revealed is not greater certainty in a settled meaning but rather an origin story that bears almost no resemblance to how government lawyers use the term today. A backward chronological methodology traces and ultimately reveals a lost meaning that deserves consideration in today's debates about not only the fate of Bahlul's prosecution, but indeed the jurisdiction of military commissions generally and the very structure of the law of war itself. What is the law of war? Is it a body of international law or is it partly a creature of domestic law? It goes without saying that the history of the concept of the "common law of war" should be of grave interest not only to observers of Bahlul's case, but indeed anyone who cares about the legal regulation of war. At issue in this one phrase is not just the jurisdiction of a single individual's case but, more importantly, a generalized theory of the law of war as a sub-component of general international law.

The story begins, in Part I, with the government's invocation of the common law of war in the Al Bahlul habeas litigation, and then proceeds, in Part II, to examine the references to the common law of war in the Quirin German saboteurs case during World War II. In Part III, this Article then examines the use of the phrase during the prosecution of the Lincoln assassins (when, as now, few people understood the term). Part IV of this Article will trace the phrase to its introduction by Francis Lieber in his codification of the laws of war, and will explain where and why Lieber referred to the common law of war as a regulating device for civil wars. Chief among the reasons for Lieber's invocation was that the U.S. Civil War was, in fact, a civil war which had to be regulated by a body of law that applied in noninternational armed conflicts. Finally, Part V will explain the origin of the concept of the "common law of war" as developed by early natural law theorists such as Emmerich de Vattel. ${ }^{13}$ In short, the phrase "common law of war" had nothing to

13. See Emmerich de Vattel, The Law of Nations; or Principles of The Law of Nature, Applied to The Conduct And Affairs of Nations And Sovereigns 295, at 426-27 (Joseph Chitty ed., Philadelphia, T. \& J. W. Johnson, Law Booksellers 1844) (explaining the 
do with a domestic body of law, but rather a proto-international set of customary rules regarding warfare which applied during all armed conflicts-whether they were classified as international or internal wars. ${ }^{14}$ What was "common" about the law was that it applied both to the state and to the rebel group that it was fighting. In other words, it was a conceptual tool-a functional analog-for explaining how the laws of war could apply not just to nation-states, but also to non-state actors which otherwise could not be regulated by the laws of war. Simply put, the common law of war was the exact same thing as the international law of war except applied during internal conflicts. Defined as such, the phrase does none of the conceptual work that the U.S. government expects it to do in its filings in the $A l$ Bahlul litigation.

\section{AL BAHLUL'S CONSPIRACY}

Bahlul was captured in Pakistan by Pakistani forces in $2001 .{ }^{15} \mathrm{He}$ was subsequently transferred to the custody of U.S. armed forces and sent to the detention facility at Guantanamo Bay, Cuba, and eventually placed on trial before a military commission-one of the few proceedings to run to a final verdict. ${ }^{16}$ After trial, Bahlul was convicted of conspiracy, material support for terrorism, and solicitation, all offenses that are best described as inchoate in nature. ${ }^{17} \mathrm{In}$ short, Bahlul was not charged with being responsible, as an accomplice, for the 9/11 attacks; indeed, it seems nearly beyond legal dispute that the military commissions have jurisdiction over individuals charged with direct responsibility in the 9/11 attacks as

sovereign's reasons for observing "the common laws of war" when its "subjects take up arms").

14. See id.

15. See United States v. Al Bahlul, 820 F. Supp. 2d 1141, 1156 (U.S.C.M.C.R. 2011).

16. $I d$. The procedural history is complex. Bahlul was first referred by the Deputy Appointing Authority for trial before the military commission in 2004. Id. However, his trial was stayed pending the resolution of the Hamdan litigation regarding the fate of the military commissions. Id. The Supreme Court ruled in Hamdan I that the commissions violated both the Uniform Code of Military Justice and Common Article 3 of the Geneva Conventions. See $i d$. Congress responded by passing the Military Commissions Act of 2006. See id. In 2008 the Convening Authority again referred Bahlul back to the commission for prosecution. Id. The trial was held in 2008 and resulted in a conviction and sentence of life imprisonment. Id. at 1156-57. For a full recitation of this procedural history, see $i d$.

17. See Al Bahlul v. United States, 767 F.3d 1, 3 (D.C. Cir. 2014). 
conspirators or accomplices. However, Bahlul's case was built entirely on inchoate offenses because the government was prosecuting him for his contributions to the al-Qaeda cause and the organization's operations directed at the United States-terrorist attacks that never came to fruition because Bahlul and others like him were captured and taken to Guantanamo Bay.

On appeal, both before the U.S. Court of Military Commission Review and the D.C. District Court, Bahlul argued that the inchoate offenses were not punishable at military commissions because, inter alia, the commission's jurisdiction was circumscribed by the outer boundaries of the international law of war, and the inchoate offenses that formed the basis of his conviction were not part of the international law of war. ${ }^{18}$ After consideration of these and other arguments, the D.C. Circuit, sitting en banc, concluded in July 2014 that Bahlul's convictions for material support for terrorism and solicitation were unconstitutional because they violated the Ex Post Facto Clause of the Constitution. ${ }^{19}$ However, the panel upheld the conspiracy charges. ${ }^{20}$

18. Brief for Petitioner at 17, Al Bahlul, 767 F.3d 1 (No. 11-1324), ECF No. 1362978 ("The inchoate charges of conspiracy and solicitation to commit war crimes have been explicitly rejected from the law of war. Going back at least to the Civil War, the United States has not recognized inchoate war crimes."). For more on the status of conspiracy under international law, see Juliet R. Amenge OKoth, The Crime of Conspiracy in International Criminal LAW 25-42 (2014).

19. Al Bahlul, 767 F.3d at 17-18.

20. Id. at 18-19. The panel concluded that the conspiracy conviction was not plain error because the conduct already violated 18 U.S.C. $\$ 2332(\mathrm{~b})$ : "It is not 'plain' that it violates the Ex Post Facto Clause to try a pre-existing federal criminal offense in a military commission and any difference between the elements of that offense and the conspiracy charge in the 2006 MCA does not seriously affect the fairness, integrity or public reputation of judicial proceedings." Id. at 18 . Furthermore, the panel concluded that it was not plain error to conclude that conspiracy was a law of war violation subject to prosecution before a military commission. Id. The panel succinctly noted that the crux of the dispute was whether the relevant "law of war" should be understood in international or domestic terms. Id. at 22-23. Whatever the merits of the dispute, the court viewed both sides as reasonable interpretations, thus negating the possibility that the verdict constituted plain error:

The reason for the uncertainty is not only the divided result in Hamdan but also the High Court's failure to clearly resolve a subsidiary question: What body of law is encompassed by section 821's reference to the "law of war"? That dispute takes center stage here. Bahlul contends that "law of war" means the international law of war, full stop. The Government contends that we must look not only to international precedent but also "the common law of war developed in U.S. military tribunals."

Id. (citations omitted). 
The D.C. Circuit returned to Bahlul's case in June 2015 to once again consider the fate of his conspiracy conviction. ${ }^{21}$ A divided panel threw out that conviction as well, ${ }^{22}$ a result that is currently being heard by the entire D.C. Circuit on reconsideration and rehearing en banc. ${ }^{23}$ The U.S. government position has been, and continues to be, that the jurisdiction of the military commissions is not limited to international offenses. ${ }^{24}$ In addition to the more familiar jurisdictional nexus for international offenses, the military commissions are also constitutionally permitted, as an exception to Article III of the Constitution, to prosecute violations of the "common law of war"-the historical practice of U.S. military commissions to prosecute various offenses against the law of war. ${ }^{25}$ According to the government, it makes no difference that these offenses are not cognizable under international law and could not be prosecuted in an international forum. ${ }^{26}$ In other words, it matters little that other nations would not recognize offenses-such as conspiracy-as violating the law of war. ${ }^{27}$ What matters is that American military commissions of yore did recognize them as law of war offenses and have historically punished violators for them, including in the Quirin prosecution during World War II and in the Lincoln conspirators trial during the U.S. Civil War. ${ }^{28}$ One consequence of this governmental argument is to accept and concede a certain degree of American exceptionalism in their jurisdictional theory of military commissions. The Constitution permits military

21. Al Bahlul, 792 F.3d 1, 3 (D.C. Cir. 2015).

22. See id. Judge Rogers's opinion explicitly rejected the domestic law of war offenses argument: "The history on which the government relies fails to establish a settled practice of trying non-international offenses in law of war military commissions." Id. at 11. Judge Tatel in his concurring opinion noted that there were only three votes on the Supreme Court in Hamdan for the proposition that military commissions retain jurisdiction to try domestic offenses under the "American common law of war." Id. at 26 (Tatel, J., concurring). Conversely, the majority of the Justices viewed the U.S. common law of war "as a source of constraint, not expansion." Id. at 9 (majority opinion) (citing Hamdan I, 548 U.S. 557, 613 (2012)).

23. See Al Bahlul, No. 11-1324, 2015 U.S. App. LEXIS 16967, at *4 (D.C. Cir. Sept. 25, 2015) (per curiam).

24. See Brief for the United States, supra note 9, at 20.

25. For more discussion of this theory, see Peter Margulies, Defining, Punishing, and Membership in the Community of Nations: Material Support and Conspiracy Charges in Military Commissions, 36 FordHam InT'L L.J. 1, 90-91 (2013).

26. See, e.g., Brief for the United States, supra note 9, at 38-41.

27. See id.

28. See id. at 35 . 
commissions to try offenses that Americans have historically viewed as law of war offenses-even if the rest of the world does not currently consider (and has never considered) them as punishable under the law of nations. ${ }^{29}$

As Steve Vladeck explains in his leading article on the subject, the jurisdiction of the military commissions is complex and undertheorized.$^{30}$ Article III of the Constitution invests the judicial function in Article III courts ${ }^{31}$ and the jury requirement embodied in the Fifth and Sixth Amendments protects the right of all individuals to have their cases heard before a jury. ${ }^{32}$ Furthermore, Article III arguably protects the rights of all individuals to have their cases heard before an Article III judge with life tenure. ${ }^{33}$ Over the years, the Supreme Court has announced various exceptions to the requirements of Article III and has allowed some cases to proceed in alternate fora. ${ }^{34}$ However, the scope and justification for these exceptions are ad hoc and lacking in a deeper normative foundation. ${ }^{35}$ Although it is clear that military justice is, in some cases, exempted from the requirements of Article III, it is unclear why and what limitations, if any, apply to that exception. ${ }^{36}$ Accord-

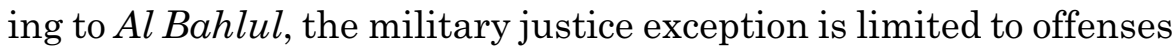
that violate the laws of war-an international body of law. ${ }^{37}$ In contrast, the government insists that the military justice exception also applies to domestic common law of war offenses. ${ }^{38}$

Although the Supreme Court has only had a few occasions to define the scope of the military commissions' jurisdiction, it did so during the Quirin case. ${ }^{39}$ Unfortunately, its statements were ambiguous and rested on false premises, which makes it extremely

29. See id. at 35-36.

30. See Stephen I. Vladeck, Military Courts and Article III, 103 GEO. L.J. 933, 937 (2015) ("[T] he military exception has increasingly become untethered from any textual or analytical moorings.").

31. U.S. Const. art. III, $\S 1$.

32. See id. amends. V, VI.

33. See Vladeck, supra note 30 , at 952 .

34. See id. at 934 .

35. See id. at $934-36$.

36. See Stephen I. Vladeck, The Laws of War as a Constitutional Limit on Military Jurisdiction, 4 J. NAT'L SECURITY L. \& POL'Y 295, 301-12 (2010).

37. See Al Bahlul v. United States, 792 F.3d 1, 22 (D.C. Cir. 2015).

38. See Brief for the United States, supra note 9, at 35-36.

39. See supra notes 8-9 and accompanying text. 
difficult to draw any firm conclusions about the Supreme Court's underlying theory of military jurisdictions. ${ }^{40} \mathrm{~A}$ full analysis of this evidence now follows.

\section{QUIRIN \& THE JURISPRUDENCE OF MISTAKES}

In 1942, Nazi saboteurs landed in the United States, on Amagansett Beach on Long Island, New York, after traveling via German submarines from Europe.$^{41}$ Each member of the group was born in Germany, spent some time living in the United States, and then returned to his home country before World War II ${ }^{42}$ During the war, each became members of the German armed services and fought for the German cause. ${ }^{43}$ The submarines landed in the United States and the saboteurs were dispatched under cover of darkness. ${ }^{44}$ Although each wore a military uniform upon arriving on shorewhen the risk of capture was greatest - they subsequently removed their uniforms and proceeded covertly to cities across the continental United States with plans to engage in acts of sabotage against American civilian installations, such as railroads and power plants. ${ }^{45}$ Less than a month after the men's arrival, though, two of them, Dasch and Burger, had a change of heart and went to the American authorities with information regarding their plot and the other saboteurs. ${ }^{46}$ At first, the story was considered so fanciful that federal agents did not believe them. ${ }^{47}$ However, once their story was confirmed, the other saboteurs were arrested. ${ }^{48}$

President Franklin D. Roosevelt insisted that the would-be saboteurs be prosecuted before a military commission rather than a civilian court, and that they be sentenced to death. ${ }^{49}$ The petition-

\footnotetext{
40. See infra Part II.

41. Ex parte Quirin, 317 U.S. 1, 21 (1942).

42. Id. at 20 .

43. Id. at 21 .

44. Id.

45. Id.; see also Robert E. Cushman, Ex Parte Quirin et al.-The Nazi Saboteur Case, 28 CoRnell L.Q. 54, 54-55 (1942).

46. See Cass R. Sunstein \& Jack L. Goldsmith, Military Tribunals and Legal Culture: What a Difference Sixty Years Makes 2, 19 Const. Comment. 261, 263 (2002).

47. See id.

48. $I d$.

49. See id. at 264 (citing Memorandum from President Franklin D. Roosevelt to Attorney
} 
ers filed habeas petitions with the U.S. Supreme Court, which heard their case on an expedited basis. ${ }^{50}$ In a rush to hand down the decision before the saboteurs were executed-which might have damaged the legitimacy of the Supreme Court by revealing it as an ineffectual institution in matters of national security-the Supreme Court issued a hastily rendered per curiam decision which noted only that the appeal was denied. ${ }^{51}$ Several months later, the Court issued a formal opinion explaining its reasoning regarding the constitutionality of the military commissions. ${ }^{52}$ The relevant passage reads:

It is no objection that Congress in providing for the trial of such offenses has not itself undertaken to codify that branch of international law or to mark its precise boundaries, or to enumerate or define by statute all the acts which that law condemns. An Act of Congress punishing "the crime of piracy, as defined by the law of nations" is an appropriate exercise of its constitutional authority, Art. I, § 8, cl. 10, "to define and punish" the offense, since it has adopted by reference the sufficiently precise definition of international law. Similarly, by the reference in the 15th Article of War to "offenders or offenses that ... by the law of war may be triable by such military commissions," Congress has incorporated by reference, as within the jurisdiction of military commissions, all offenses which are defined as such by the law of war, and which may constitutionally be included within that jurisdiction. Congress had the choice of crystallizing in permanent form and in minute detail every offense against the law of war, or of adopting the system of common law applied by mili-

Gen. Francis Biddle (June 30, 1942) (on file with the Franklin D. Roosevelt Presidential Library)). Dasch and Burger were spared the death penalty when President Roosevelt commuted their sentences to life in prison in recognition of their decision to implicate their fellow Nazi saboteurs. See id. at 269. The others were all executed. See id.

50. See id. at 5. Justice Scalia later referred to the decision as "not th[e] Court's finest hour." Hamdi v. Rumsfeld, 542 U.S. 507, 569 (2004) (Scalia, J., dissenting).

51. See Ex parte Quirin, 317 U.S. 1, 18-19 (1942) (presenting verbatim the transcript of that per curiam decision).

52. See id. at 1. The Supreme Court also upheld the commissions' authority to prosecute offenses pursuant to the common law of war in Yamashita. See In re Yamashita, 327 U.S. 1, 20 (1946). This residual power was codified in Article of War 15 and later at 10 U.S.C. $§ 821$ (2012). For a discussion of this codification, see American Bar Association Task Force on Terrorism and the Law, Report and Recommendations on Military Commissions, ARMY LAW., Mar. 2002, at 8-11. 
tary tribunals so far as it should be recognized and deemed applicable by the courts. It chose the latter course.

By universal agreement and practice, the law of war draws a distinction between the armed forces and the peaceful populations of belligerent nations and also between those who are lawful and unlawful combatants. Lawful combatants are subject to capture and detention as prisoners of war by opposing military forces. Unlawful combatants are likewise subject to capture and detention, but in addition they are subject to trial and punishment by military tribunals for acts which render their belligerency unlawful. The spy who secretly and without uniform passes the military lines of a belligerent in time of war, seeking to gather military information and communicate it to the enemy, or an enemy combatant who without uniform comes secretly through the lines for the purpose of waging war by destruction of life or property, are familiar examples of belligerents who are generally deemed not to be entitled to the status of prisoners of war, but to be offenders against the law of war subject to trial and punishment by military tribunals. ${ }^{53}$

The Court's analysis seems simple enough: Congress has allowed military commissions to try offenses against the law of nations but has not explicitly codified which offenses qualify under that definition. ${ }^{54}$ Then comes the Court's oblique reference to the "system of common law applied by military tribunals. ${ }^{155}$ The question is what this phrase means. Does it include noninternational offenses?

One way to get a handle on the Court's invocation of the phrase "system of common law" is to ask what the Supreme Court did in the Quirin case. In Quirin, the Court upheld the jurisdiction of the military commissions to prosecute a spy who "without uniform comes secretly through the lines for the purpose of waging war by destruction of life or property." ${ }^{56}$ This was, apparently, how the Supreme Court viewed Haupt, Quirin, and their confederates-as unlawful belligerents who surreptitiously and covertly crossed military lines without complying with the functional requirements

53. Quirin, 317 U.S. at 29-31 (omission in original) (footnotes and citations omitted).

54. See id.

55. Id. at 30; see also id. at 34 (referring to "applicable principles of the common law of war").

56. Id. at 31 . 
of belligerency (such as wearing a distinctive emblem or carrying their arms openly). ${ }^{57}$ Now, the question is what lessons one should draw from this holding for other military commissions cases, like Bahlul's, that have nothing to do with spying.

Here is one possible interpretation: The Supreme Court upheld the jurisdiction of the military commissions in a case involving spies and saboteurs, who are unprivileged combatants. ${ }^{58}$ However, being a spy or an unprivileged combatant is not a violation of international law; it is, rather, a violation of domestic law. ${ }^{59}$ Therefore, by extension, the Supreme Court's holding in Quirin stands for the proposition that the military commissions have constitutional authority to try domestic law of war offenses. ${ }^{60}$

Why is spying a domestic law offense? It certainly appears, at first glance, like a violation of the international law of war, but it is not. There is no convention or international treaty that directly outlaws spying, although the literature and practice of modern warfare is replete with examples of spies and saboteurs being captured behind enemy lines and sentenced for treachery. ${ }^{61}$ However, there is a big difference between a recognized international offense and the lack of an international immunity that precludes prosecution for a domestic offense. ${ }^{62}$

The best and most convincing view is that spying involves unprivileged conduct because the spy or the saboteur is acting perfidiously_not carrying arms openly, not wearing a uniform - and therefore is not entitled to the combatant's privilege. ${ }^{63}$ The combatant's privilege is an international immunity that prohibits states from prosecuting legitimate enemy combatants for their perpetration of

57. See id. at $21,36-38$.

58. See id. at 31.

59. See Brief for the United States, supra note 9, at 40.

60. See id. at 40-41.

61. See Major David A. Anderson, Spying in Violation of Article 106, UCMJ: The Offense and the Constitutionality of Its Mandatory Death Penalty, 127 MIL. L. REV. 1, 14-15 (1990) (explaining that spying is not a violation of international law under Article 24 of the Hague Regulations).

62. For more discussion of the privilege of combatancy, see generally Jens David Ohlin, The Combatant's Privilege in Asymmetric and Covert Conflicts, 40 YALE J. InT'L L. 337 (2015).

63. See Yoram Dinstein, The Conduct of Hostilities Under the LaW of International Armed Conflict 51-52 (2d ed. 2010); Sean Watts, Present and Future Conceptions of the Status of Government Forces in Non-International Armed Conflict, 88 InT'L L. STUD. 145, 151-52 (2012) (considering combatant's privilege as immunity versus affirmative license). 
regular acts of battlefield belligerency. ${ }^{64}$ Legitimate combatants are entitled to POW status instead of criminal prosecution, in conformance with the Geneva Conventions. ${ }^{65}$ In the absence of such immunity, the spy or saboteur can be prosecuted and punished-but in this case the substantive offense is a domestic crime, not an international crime ${ }^{66}$ On this view, Quirin stands for the proposition that military commissions have the authority to prosecute domestic law of war offenses.

This interpretation would seem cut and dry. But there is a problem with it. The problem is that the Supreme Court in Quirin was apparently operating under the impression that spying was a violation of international law. ${ }^{67}$ Indeed, the Court described the commission's law of war jurisdiction in purely international terms-a total misnomer if it had believed that spying and sabotage were domestic offenses. For example, the Court noted: "From the very beginning of its history this Court has recognized and applied the law of war as including that part of the law of nations which prescribes, for the conduct of war, the status, rights and duties of enemy nations as well as of enemy individuals." ${ }^{88}$ This language makes clear that the Court viewed the relevant offenses it was discussing as violations of the law of nations.

The Court's assessment was made even clearer in its next sentence:

Congress, in addition to making rules for the government of our Armed Forces, has thus exercised its authority to define and punish offenses against the law of nations by sanctioning, within

64. See Adil Ahmad Haque, Law and Morality at War, 8 CRIM. L. \& PHIL. 79, 88 (2012).

65. See Geneva Convention Relative to the Treatment of Prisoners of War art. 4, Aug. 12, 1949, 6 U.S.T. 3316, 75 U.N.T.S. 135.

66. See Richard Baxter, So-Called 'Unprivileged Belligerency': Spies, Guerrillas, and Saboteurs, in Humanizing the Laws of War: Selected Writings of Richard Baxter 37, 44 (Detlev F. Vagts et al. eds., 2013).

67. See Jonathan Hafetz, Policing the Line: International Law, Article III, and the Constitutional Limits of Military Jurisdiction, 2014 WIs. L. REv. 681, 729 ("Additionally, while spying may not violate international law, judicial acknowledgment of military jurisdiction over spying in Quirin was premised on the assumption that spying does in fact constitute such a violation. Thus, even though the Supreme Court may have misconstrued the content of international law in addressing spying, it validated a mode of interpretation that looks to international law to define the constitutional boundaries of military commission jurisdiction." (footnotes omitted)).

68. Ex parte Quirin, 317 U.S. 1, 27-28 (1942) (emphasis added). 
constitutional limitations, the jurisdiction of military commissions to try persons for offenses which, according to the rules and precepts of the law of nations, and more particularly the law of war, are cognizable by such tribunals. ${ }^{69}$

Again, this statement makes it abundantly clear that the Quirin Court viewed the law of war in exclusively international terms, and, by logical extension, viewed the crimes in Quirin as violations against the law of nations.

Other commentators have largely agreed with this interpretation of the Quirin Court's analysis, though it is unclear what conclusions should be drawn from it. ${ }^{70}$ Here is the essential dilemma: One can interpret the Supreme Court's holding based on what it did, or one can interpret the Court's holding based on what it said it did-and what it said it did involved a cognitive error. In reality, the Supreme Court upheld the commission's jurisdiction for a domestic crime. ${ }^{71}$ But the Supreme Court said (erroneously, it turned out) that it was upholding the commission's jurisdiction over an international offense. How do you interpret a court's holding when that holding is based on a mistake? Do you interpret it subjectively or objectively?

The confusion here was not lost on some commentators even immediately following the Quirin decision. Writing in 1951, the leading American expert on the laws of war, Richard Baxter, concluded that "espionage is not in violation of the law of nations" and that the Supreme Court was deeply confused about this point in Quirin:

[T] he tribunal was led by the somewhat imprecise distinction often made between "lawful" and "unlawful" combatants to conclude that failure to qualify as a lawful combatant could be described as a violation of international law. If, indeed, the Court was proceeding on the assumption that the law of nations forbids the employment of spies and espionage itself, that view, it is submitted, fails to find support in contemporary doctrine regarding such activities in wartime. ${ }^{72}$

69. Id. at 28 .

70. See, e.g., Cushman, supra note 45 , at 58-60.

71. See Quirin, 317 U.S. at 27-28.

72. BAXTER, supra note 66 , at 44 . 
Baxter even went so far as to conclude, "[T] he characterization of such conduct as a violation of international law arises, it is submitted, from a fundamental confusion between acts punishable under international law and acts with respect to which international law affords no protection." ${ }^{\text {"3 }}$ In other words, the Quirin defendants were not entitled to the combatant's privilege and were therefore subject to prosecution for violating domestic offenses. ${ }^{74}$

Unfortunately, Baxter never stated directly his views regarding whether this undermined Quirin's central holding. Instead, he simply noted (almost in passing) that "there is no doubt that secret agents of this nature are subject to trial under the statutes or military common law of the captor." ${ }^{75}$ Still, the question remains as to where such spies and saboteurs are subject to prosecution-an Article III court or a military commission? International law on that question, as Baxter rightly notes, is completely silent. ${ }^{76}$ Instead, that question is governed by domestic constitutional law and the constitutional limits embodied in the military justice exception to Article III requirements (whatever they are).

The result of this analysis is a fundamental ambiguity regarding whether the Quirin decision supports the government's position in $A l$ Bahlul that military commissions retain authority to prosecute domestic offenses. Since the Supreme Court assumed in its decision that Quirin and his codefendants had committed an international offense, the Quirin holding is at best a conceptual tangle of faulty assumptions, and at worst evidence of the opposite conclusion: that military commissions are limited to prosecuting offenses that violate the law of nations, not domestic offenses.

\section{THE LINCOLN ASSASSINATION}

The government's position regarding the jurisdiction of military commissions to try domestic law of war offenses-so-called violations of the "common law of war"-does not rely exclusively on Quirin. The Lincoln assassination saga arguably provides support for its argument, in part because the resulting prosecutions were

73. See id. at 52-53.

74. See supra note 66 and accompanying text.

75. BAXTER, supra note 66 , at 52 .

76. See id. at 38-42. 
based on conspiracy charges and also because the defendants were brought before the military commission under the "common law of war." ${ }^{\text {"77 }}$ But on closer inspection, that support is deeply problematic for two reasons.

First, the prosecution of the Lincoln conspirators, though nominally based on conspiracy, was not based on conspiracy as an inchoate offense. ${ }^{78}$ The whole point of the Lincoln assassination is that the conspirators completed the target crime - the crime to which the conspiracy was directed. Moreover, the official charges included the fact of Lincoln's death in the description of the crime. ${ }^{79}$ Therefore, the Lincoln case did not deal with the distinctively common law category of conspiracy as an inchoate offense. Rather, it dealt with conspiracy as a pathway for convicting a defendant for participating in a criminal plan that brought about a completed crime. Although it is unclear whether the defendants were charged with conspiracy as a substantive offense or conspiracy as a mode of liability for a murder and treason prosecution, ${ }^{80}$ the undeniable fact is that the case was not inchoate in nature. It therefore cannot stand as an example of a trial of inchoate conspiracy before a military commission.

Second, and more importantly, the stray references to the "common law of war" in the Lincoln conspirators' case were just as nonsensical and confusing then as they are today. Although the Judge Advocate General asserted that the charges were made pursuant to the "common law of war," the transcripts reveal that even then the phrase was utterly confounding to the trial participants. For example, consider General Ewing's speech made to the military commission on behalf of defendant Samuel A. Mudd:

77. See Brief for the United States, supra note 9, at 35 n.5.

78. See Al Bahlul v. United States, 792 F.3d 1, 12 (D.C. Cir. 2015).

79. Charge and Specification Against David E. Herold, George A. Atzerodt, Lewis Payne, Michael O'Laughlin, Edward Spangler, Samuel Arnold, Mary E. Surratt, and Samuel A. Mudd, in The Assassination of President Lincoln and the Trial of the Conspirators 18, 19 (Benn Pitman ed., New York, Moore, Wilstach \& Baldwin 1865).

80. See id. 
May it please the Court: If it be determined to take jurisdiction here, it then becomes a question vitally important to some of these parties - a question of life and death-whether you will punish only offenses created and declared by law, or whether you will make and declare the past acts of the accused to be crimes, which acts the law never heretofore declared criminal: attach to them the penalty of death, or such penalty as may seem meet to you; adapt the evidence to the crime and the crime to the evidence, and thus convict and punish. This, I greatly fear may be the purpose, especially since the Judge Advocate said, in reply to my inquiries, that he would expect to convict "under the common law of war." This is a term unknown to our language ... wholly undefined and incapable of definition. It is, in short, just what the Judge Advocate chooses to make of it. It may create a fictitious crime, and attach to it arbitrary and extreme punishment, and who shall gainstay it? The laws of war-namely, our Articles of War-and the habitual practice and mode of proceeding under them, are familiar to us all; but I know nothing, and never heard or read of a common law of war, as a code or system under which military courts or commissions in this country can take and exercise jurisdiction not given them by express legal enactment or constitutional grant. ${ }^{81}$

It is amazing to read these anxieties, expressed so long ago, regarding a concept that is still today deployed by the government to justify prosecution before a military commission. Indeed, Ewing specifically complained about his inability to defend, consistent with due process, his client against a charge falling under the "common law of war" when the term was impossible to understand. ${ }^{82}$

At first glance, it is hard to explain why the military commission prosecuting the Lincoln assassination conspirators would have relied on the common law of war in establishing the commission's

81. Thomas Ewing, Jr., Argument of the Law and Evidence in the Case of Dr. Sam'l A. Mudd, in The Assassination of President Lincoln and the Trial of the Conspirators, supra note 79 , at 318 .

82. Id. at 319. ("But of the common law of war, as distinct from the usages of military courts, in carrying out and executing the Articles of War, I know nothing, and, on examining the books, I find nothing. All that is written down in books of law or authority I am, or ought to be, prepared to meet; but it were idle and vain to search for and combat a mere phantom of the imagination, without form and void."). 
jurisdiction. Where did the concept come from? Ewing's speech makes clear that the phrase was not in common usage at the time. ${ }^{83}$ The answer lies in the phrase's centrality in the Lieber Code, drafted on behalf of the Lincoln Administration by Francis Lieber, an expert on the laws of war, a law school lecturer, and an admirer of the philosophy of Immanuel Kant and the natural law theorists. ${ }^{84}$ Lincoln asked Lieber to draft the Code, which was then designated as General Order Number 100 and given to Union officers. ${ }^{85}$ As such, the Lieber Code quickly became a foundational document regarding the legal regulation of armed conflict. Moreover, as John Witt explains in his book Lincoln's Code, the Code's application involved far more than the regulation of warfare conduct. ${ }^{86}$ It also spoke to pertinent issues regarding presidential power during armed conflict—a central concern for President Lincoln, who asserted numerous unprecedented powers which he viewed as essential for the conduct of the war. ${ }^{87}$ Not least among these was the power to issue the Emancipation Proclamation and free the slaves. ${ }^{88}$ According to Witt, Lincoln's authority to issue the Proclamation was justified, in part, by the claim that the action was essential for the Union's war effort. ${ }^{89}$ The Lieber Code was a key piece of the legal and political architecture of Lincoln's presidential powers argument because the Lieber Code, particularly in Articles 14, 15, and 16, laid out a broad vision of the concept of "military necessity"-actions necessary for the war effort. ${ }^{90}$ Lincoln justified the Proclamation, among other presidential actions, as military necessity, and the

83. See id.; see also William E. Doster, Lincoln and Episodes of the Civil War 261 (1915) (noting that "[t]he crimes were not defined by any known rules of law but were vaguely called offenses against the 'common law of war"').

84. For a richly drawn portrait of Lieber, see generally John FABIAN WitT, LinCOLN'S Code: The LaWs of WAR in American History (2012).

85. Francis Lieber, Instructions for the Government of Armies of the United States in the Field art. 57 (Washington, Government Printing Office 1898) [hereinafter Lieber Code], http://www.loc.gov/rr/frd/Military_Law/pdf/Instructions-gov-armies.pdf [https:// perma.cc/DZ32-WAVH].

86. See WiTT, supra note 84 , at 345 .

87. See id. at 238.

88. See id. at 239.

89. See id.

90. See Lieber Code, supra note 85, arts. 14-16. For a longer discussion of military necessity, see Jens David Ohlin, The Duty to Capture, 97 Minn. L. REv. 1268, 1297-1302 (2013). 
Lieber Code provided one articulation of the centrality of military necessity as a pillar of the laws of war. ${ }^{91}$ As such, the Lieber Code was of central importance to the legal theory of the Lincoln administration. And as the following Part demonstrates, the "common law of war" concept appears repeatedly in the Lieber Code, so it is no surprise that the phrase was in the air and being invoked during the Lincoln conspirators' trial just a few years after the Lieber Code was first adopted.

\section{THE LIEBER CODE}

The Lieber Code makes multiple references to the "common law of war." First, Article 13 defines the outer limits of military jurisdiction. ${ }^{92}$ Lieber notes that military jurisdiction can come from either statute or the common law of war. ${ }^{93}$ He states that "[m]ilitary offenses under the statute law must be tried in the manner therein directed; but military offenses which do not come within the statute must be tried and punished under the common law of war." ${ }^{\text {"94 }}$ The question is what the "common law of war" means in this context.

The phrase reappears later in the Code. Article 19 suggests that, whenever possible, commanders should inform the enemy of their intent to attack and give noncombatants a chance to escape before the attack begins, though the next statement says that surprise is sometimes a military necessity and "it is no infraction of the common law of war to omit thus to inform the enemy." ${ }^{95}$ Similarly, Article 101 states that "deception in war ... is consistent with honorable warfare" and that the common law of war permits "capital punishment for clandestine or treacherous attempts to injure an enemy, because they are so dangerous, and it is difficult to guard against them. ${ }^{\text {"96 }}$ Finally, Article 103 clarifies that "spies, war-traitors, and war-rebels are not exchanged according to the

91. See WiтT, supra note 84, at 234, 338 ("In Lieber's hands, military necessity was both a broad limit on war's violence and a robust license to destroy.”).

92. See Lieber Code, supra note 85, art. 13.

93. See id.

94. See id. arts. 13-15.

95. Id. art. 19.

96. Id. art. 101 . 
common law of war." ${ }^{97}$ Article 103 clarifies that such an exchange requires a government-authorized "special cartel."

Why does Lieber make repeated references to the "common law of war," and what did he mean by it? The answers can be found in the Lieber Code's dual purposes. First, it was designed to apply in a civil war between the Union and Confederacy. ${ }^{99}$ Second, it was designed to be a general expression of the laws and usages of war. ${ }^{100}$ These two components stand in some tension with each other. Generally, the law of war is viewed as coming from international law-from the body of law that regulates interactions among sovereign states. In that sense, the laws of war are a component of the law of nations. But since a civil war is an internal conflict between a government and rebels, how do the laws of war apply to it? After all, there is nothing terribly international about a civil war.

Part of the answer lies in the fact that the U.S. Civil War was not just any civil war-instead, it was the functional equivalent of an international conflict. ${ }^{101}$ Lincoln pursued the war with the South using a mixed theory of war. ${ }^{102}$ In one breath, Lincoln acted as if the war was a civil war-a rebellion that the federal government had every authority to put down. ${ }^{103}$ At the same time, Lincoln treated the Confederacy as a recognized belligerent, a point that the Supreme Court made in the Prize Cases when it affirmed application of international rules of capture regarding southern ships. ${ }^{104}$ Indeed, the mixed theory of the war throws into sharp relief the degree to which the international laws of war are both a license and a constraint at the same time. ${ }^{105}$ In one sense, the international

\footnotetext{
97. $I d$. art. 103.

98. Id.

99. See WitT, supra note 84 , at 345 .

100. See id.

101. See Stephen C. Neff, Justice in Blue and Gray: A Legal History of the Civil War 18-19 (2010) (indicating British and French recognition of the Confederacy as a belligerent power); 2 L. Oppenheim, International Law: A Treatise 204 \& n. 2 (H. Lauterpacht ed., 7th ed. 1952) (arguing that civil war between states in a federal system is international war even in the absence of recognized belligerency from third-party states).

102. NefF, supra note 101, at 22 (referring to a "dualistic approach").

103. Id. at 15 ; see WITT, supra note 84 , at 151 ("[P]reservation of the Union could be a war and a criminal law enforcement action at the same time.").

104. The Prize Cases, 67 U.S. (2 Black) 635, 670 (1863) (determining that Lincoln's proclaimed blockade of southern ports was "conclusive evidence" that a state of war existed).

105. See WiтT, supra note 84, at 234.
} 
laws of war constrain state behavior and prevent governments from engaging in acts during public wars that they are free to commit during civil wars, which are regulated by international law to a lesser degree. But on the other hand, a state of war (in the international sense) confers upon the government license to engage in acts that were considered essential for Lincoln, including imposing martial law and signing the Emancipation Proclamation. ${ }^{106}$

Nonetheless, the Lieber Code makes clear that the laws of war apply to both international and civil conflicts. ${ }^{107}$ But what is the conceptual and legal foundation for applying the laws of war during a noninternational conflict? By definition the foundation cannot be international law because these conflicts are not international. Instead, the answer can be found in natural law. Lieber states in Article 40 of his Code that "[t]here exists no law or body of authoritative rules of action between hostile armies, except that branch of the law of nature and nations which is called the law and usages of war on land." ${ }^{108}$ So it is clear that, for Lieber at least, the laws of war come from natural law and as such apply in civil wars as well. Also, Lieber's definition of war-which he believed could be regulated by law-was broad enough to include all types of armed conflicts, including internal conflicts: War is a "protracted physical contest between large numbers."109

Again, the question is how the laws of war can apply in a noninternational armed conflict. As indicated above, Lieber was enamored with natural law theory and he drew from it a central

106. But see Ex parte Milligan, 71 U.S. (4 Wall.) 2, 127 (1866) (holding martial law unconstitutional); Ex parte Merryman, 17 F. Cas. 144, 145 (C.C.D. Md. 1861). For more discussion of these and other cases, see Steven J. Bucklin, To Preserve These Rights: The Constitution and National Emergencies, 47 S.D. L. REV. 85, 87 (2002) ("Hard pressed to maintain the Union, Lincoln found it necessary to suspend some of the fundamental rights of American citizens in order to prosecute the war.”).

107. See Lieber Code, supra note 85, arts. 149-57 (discussing insurrection and civil war). Indeed, Lieber concludes in Article 154 that "[t]reating, in the field, the rebellious enemy according to the law and usages of war has never prevented the legitimate government from trying the leaders of the rebellion or chief rebels for high treason, and from treating them accordingly, unless they are included in a general amnesty." Id. art. 154. This suggests, by omission, that Lieber viewed regular soldiers fighting on the battlefield as privileged belligerents and, although subject to prosecution for treason, not subject to prosecution for murder for regular acts of battlefield killing.

108. Id. art. 40.

109. See Francis Lieber, Law and Usages of War, Lecture at Columbia Law School (1861) (on file with the Johns Hopkins University Milton S. Eisenhower Library). 
insight: natural law applied to and governed the relationship between formal belligerents in a noninternational conflict. ${ }^{110}$ This simple insight explains his use of the phrase "the common law of war" in the Code. The common law of war was the law of war that was "common" to all sides of an armed conflict. It was common because its authority stemmed not just from the international system, but more basically from natural law, a source of authority that was not limited to sovereign states as its subjects.

Consequently, the best explanation of the phrase the "common law of war" is that it represented a functional surrogate to the international laws of war that applied in noninternational conflicts. The "common" of "common law of war" was that it was common to all sides of a conflict, even though one party was not a sovereign state within the international system. The customary restrictions of honorable warfare constrained sovereign states in public wars by virtue of the law of nations; those same customary restrictions of honorable warfare constrained both parties of a civil war by virtue of the common law of war, which applied equally to governments and rebel forces who organized themselves as belligerent forces. The common law of war was derived not just from the practice of states, but also-and more fundamentally-from the requirements of natural reason.

Jurists' usage during the earliest years of the American republic confirms this reading of the phrase the "common law of war." The 1790 case of Dulany $v$. Wells illustrates this understanding of the term. ${ }^{111}$ The case involved a seemingly pedestrian dispute: namely, a demand for payment of a debt stemming from a bond instrument. ${ }^{112}$ The General Court of Maryland considered whether the War of Independence had extinguished the obligation to repay a private debt to a British subject. ${ }^{113}$ The court concluded that the obligation endured despite the war between the United States and Britain. ${ }^{114}$ In making this determination, the court extensively referenced natural law, which endured between the United States and

110. See id.

111. 3 H. \& McH. 20, 20-24 (Md. Gen. 1790), rev'd, (June 1795)

112. See id. at 20.

113. See id. at 21-22.

114. See id. at 80 . 
Britain even when the two entities went to war. ${ }^{115}$ In answering the objection that the war was "different from the usual case of war between two different nations," the court concluded that the common law of war, and hence natural law, applied to belligerents in a civil war:

That a civil war breaks the bonds of society and government, or at least suspends their force and effect, produces in the nation two independent parties, considering each other as enemies, and acknowledging no common judge. That these two parties are in the case of two nations at war. That the common laws of war are to be observed on both sides. That while subjects who take arms against their sovereign acknowledge his authority, the effects of war as to the acquisition of property do not take place; but when they cease to acknowledge the authority of the sovereign, and the nation is divided into two parts, absolutely independent, and acknowledging no common superior, the state is dissolved, and the war betwixt the two parties in every respect is the same with that of a public war between two different nations. ${ }^{116}$

Dulany clearly demonstrates that the common law of war is a surrogate to the law of nations, except that it applies in noninternational conflicts. ${ }^{117}$ Ultimately, both bodies of law stem from the same source: natural law. In cases of international law, judges refer to the laws of war that stem from the laws of nations and natural law; in cases of civil war, judges refer to the laws of war embodied in the common law of war, which also has its genesis in natural law. Both regulate the behavior and interrelation of the parties to an armed conflict. Consequently, the most accurate description of the common law of war is the international law of war applicable in noninternational conflicts. That is precisely how the phrase was used in the century before Lieber first put the phrase in his Code.

I should add that although an understanding of this phraseology was subsequently lost to lawyers, the phrase is better understood by

115. See, e.g., id. at 25.

116. Id. at 74 .

117. Dulany is not cited for the value of its holding on the matter of the debt obligation, which was reversed on appeal. The case is cited for evidence of the historical usage, and meaning, of the phrase "common law of war." 
historians who write about that period. For example, Howard Jones in his book Union in Peril correctly notes that the "common law of war" applied to civil wars, a position that goes all the way back to the natural law theorist Emmerich de Vattel. ${ }^{118}$ The fact that the common law of war applied to the Union's war against the Confederacy was of no small consequence to either law or international relations. Because the U.S. Civil War was governed by the common law of war, the international rules regarding neutrality applied as well. In accordance with those rules, third parties were entitled to declare their neutrality to the conflict-which meant that as long as they refused to grant assistance to either side of the conflict, they could not be considered a belligerent or party to the war. ${ }^{119}$ As such, they could not be attacked. In international wars, this rule stemmed from the law of nations; in civil wars that were large enough to implicate the rules regarding neutrality, the rule stemmed from the common law of war.

The Supreme Court implicitly recognized the legitimacy of the common law of war in the Prize Cases, when the Court asserted that the international rules regarding capture of vessels applied because Lincoln had blockaded the southern ports, an action that indicated that the administration viewed the Confederacy as a belligerent in an armed conflict. ${ }^{120}$ Although the Supreme Court recognized that the international rules regarding capture applied during the Civil War, the Court did not view the conflict with the Confederacy as an international conflict. ${ }^{121}$ Rather, the Court viewed the conflict as a civil war. ${ }^{122}$ But even civil wars are governed by natural law through the common law of war, as the Court noted when it quoted Vattel: "This being the case, it is very evident that the common laws of war-those maxims of humanity, moderation, and honour-ought

118. See Howard Jones, Union in Peril: The Crisis over British Intervention in the Civil War 235 n.22 (1992).

119. See NeFF, supra note 101, at 167-68.

120. The Prize Cases, 67 U.S. (2 Black) 635, 673 (1863) (“[A] civil war such as that now waged between the Northern and Southern States is properly conducted according to the humane regulations of public law as regards capture on the ocean.").

121. Id. at 674 (noting that residents of the southern states were "liable to be treated as enemies, though not foreigners").

122. Id. at 667 (noting that the existence of the civil war was "a fact in our domestic history which the Court is bound to notice and to know"). 
to be observed by both parties in every civil war." ${ }^{123}$ In the absence of the common law of war as a quasi-international body of law regulating the conduct of noninternational conflicts, the Prize Cases make no sense at all.

\section{THE NATURAL LAW ERA}

It now becomes essential to provide a larger explanation of the role played by the phrase "common law of war" for natural law theorists. The previous Parts of this Article have tried to draw a direct line back in time from Al Bahlul, to Quirin, to the Lincoln conspirators' case, and then the Lieber Code. Ultimately, the common law of war is a creature of natural law and must be understood in that context. Indeed, part of the problem with commentators' inability to correctly decipher the phrase is their ignorance of natural law, which has faded as a jurisprudential ground for the law. ${ }^{124}$ Whether one believes in natural law as a foundation for modern lawmaking, it is essential to at least understand natural law so as to correctly interpret phrases that first acquired their meaning and structure during the natural law era. I submit that the "common law of war" is one such phrase. It cannot be understood independent from its natural law genesis.

The idea of a "common law of war" played a huge role in Vattel's philosophy, as in his Law of Nations, in which he laid out a set of principles which applied to the conduct of nations. ${ }^{125}$ However, the same principles also applied in wars between non-state entities. This structure is rather confusing to modern international lawyers, who work with a cardinal separation between international armed conflicts (IACs) and noninternational armed conflicts (NIACs). ${ }^{126}$ In the modern scheme, the prohibitions embodied in the UN Charter

123. Id. (quoting VATTEL, supra note $13, \S 294$, at 425 ).

124. See generally Koh, supra note 12 , at 2608-13 (tracing the development of international law from natural law roots to modern justifications).

125. See, e.g., VATTEL, supra note $13, \S 184$, at 90.

126. See, e.g., L.C. Green, The Contemporary Law of Armed Conflict 317 (2d ed. 2000); Marko Milanovic \& Vidan Hadzi-Vidanovic, A Taxonomy of Armed Conflict, in ReseARCH HandBook on International Conflict and SECuRity LaW 256, 256 (Nigel D. White \& Christian Henderson eds., 2013). But see Tom Farer, Humanitarian Law and Armed Conflicts: Toward the Definition of "International Armed Conflict," 71 Colum. L. Rev. 37, 43 (1971). 
and rules regarding jus ad bellum only apply during IACs. ${ }^{127}$ However, the use of force in NIACs is not similarly construed-there currently is no jus ad bellum internum in the positive law. ${ }^{128}$ As for jus in bello, the codified rules are sharply divergent. In IACs, the behavior of states is constrained by all four Geneva Conventions and Additional Protocol I. ${ }^{129}$ For NIACs, the behavior of governments fighting rebels is constrained by Common Article 3 of the Geneva Convention ${ }^{130}$ and the rather anemic Additional Protocol II. ${ }^{131}$ That said, the trend in recent decisions at the ad hoc criminal tribunals has been to recognize that some of the cardinal jus in bello principles apply equally in NIACs as they do in IACs by virtue of customary international law. ${ }^{132}$

Vattel and the other natural law theorists did not operate with the same radical separation of IACs and NIACs. Rather, Vattel viewed NIACs as potentially subject to the same legal regulation when the civil war became the functional equivalent of a public war between sovereign states:

A civil war breaks the bands of society and government, or at least suspends their force and effect: it produces in the nation two independent parties, who consider each other as enemies, and acknowledge no common judge. Those two parties, therefore, must necessarily, be considered as thenceforward constituting, at least for a time, two separate bodies, two distinct societies. Though one of the parties may have been to blame in breaking the unity of the state and resisting the lawful authority, they are not the less divided in fact. Besides, who shall judge them? [W] ho shall pronounce on which side the right or the wrong lies? On earth they have no common superior. They stand therefore

127. GReEn, supra note 126, at 44; see U.N. Charter art. 2, ๆ 3 (mandating methods for settling international disputes only).

128. See Laura Perna, The Formation of the Treaty Law of Non-International ARMed Conflicts 7 (2006).

129. GREEN, supra note 126 , at 54-55.

130. Id. at 44 .

131. See Protocol Additional to the Geneva Conventions of 12 August 1949, and Relating to the Protection of Victims of Non-International Armed Conflicts (Protocol II), June 8, 1977, 1125 U.N.T.S. 609; see also GREEN, supra note 126, at 61.

132. For a discussion on this point, see Yoram Dinstein, Concluding Remarks on Non-International Armed Conflicts, 88 InT'L L. STUD. 399, 406 (2012); Milanovic \& Hadzi-Vidanovic, supra note 126, at 272 (noting the persistence of the classification scheme despite the convergence trend). 
in precisely the same predicament as two nations, who engage in a contest, and, being unable to come to an agreement, have recourse to arms. ${ }^{133}$

So for Vattel it is clear that civil wars are regulated by law. But where does the law come from? According to Vattel, it is "evident that the common laws of war-those maxims of humanity, moderation, and honour, which we have already detailed in the course of this work-ought to be observed by both parties in every civil war." ${ }^{134}$ So the common laws of war are simply the laws of war derived from natural law applicable in noninternational conflicts.

Vattel's work is replete with other references to the "common law of war." He writes that the "obligation to observe the common law of war towards each other is therefore absolute" and is "indispensably binding" on all parties. ${ }^{135}$ He uses the phrase "common law of war" as a broad category that applies in war regardless of the formal status of the parties. ${ }^{136}$ Thus, the law of war stemming from the law of nations is a particular subset of the common law of war, which applies regardless of whether the conflict is international or internal. For example, Vattel states that "no nation, under pretence of having justice on her side, ever complains of the hostilities of her enemy, while he confines them within the limits prescribed by the common laws of war." ${ }^{137}$ Vattel and the other natural law theorists were working under a paradigm that today would be referred to as IAC/NIAC convergence.

The phrase "common law of war" was not simply a creature of Vattel's work. Other natural law theorists influenced by Vattel used the same terminology to similar effect. In his Elements of International Law, Wheaton refers to the general idea behind the common law of war when he concludes that "the general usages of nations regards [civil wars] as entitling both the contending parties to all the rights of war as against each other, and even as respects neutral nations." ${ }^{138}$ Westlake had similar views and concluded that insur-

133. VATTEL, supra note $13, \S 293$, at 425 .

134. Id. § 294 , at 425 .

135. Id. $\S 295$, at 427 .

136. See, e.g., id.

137. Id. $\S 191$, at 382-83.

138. See Henry Wheaton, Elements of International Law 365 (William Beach Lawrence ed., Boston, Little, Brown \& Co., 6th ed. 1855). 
gents have belligerent rights and that "the government against which it is directed may and ought, for the sake of humanity, to treat it as war while the struggle continues." ${ }^{139}$ But somewhere along the way, the language of the common law of war was dispensed-probably at the same time that natural law departed from the scene of legal analysis.

The genealogy of the "common law of war" unearthed in this Article helps illuminate the basic structure of the law of war. The phrase "common law of war" reinforces the eternal truth that the laws of war were originally designed to be reciprocal above all else. The whole point of the law of war is that it should be universally applied to all sides of a conflict, even a noninternational conflict that rises to the level of a full civil war. Indeed, the core feature of natural law is that it binds everyone because the original normative pull emerges not from positive sources but from something far deeper - the dictates of natural reason. In this respect, all sides of a military conflict were bound to follow certain precepts regarding their behavior that stemmed from maxims of "humanity, moderation, and honour," in Vattel's famous phrase. ${ }^{140}$ In an era of war involving non-state actors such as al-Qaeda and ISIS, which are neither signatories of treaties nor formal participants in an international order that generates customary law through state action and opinio juris, it is important to remember that the laws of war were originally binding on all parties because their normative content stemmed from maxims of humanity.

Of course, we no longer live in an era of natural law. Under prevailing attitudes and methodologies, the sources of international law are limited to general principles, treaties, and custom. The application of the laws of war to actors that stand outside of that formal system-including rebel groups and non-state actors which have no formal status in the Westphalian international order-is completely confusing. As it stands now, non-state groups often-though not always-ignore the constraints embodied by the law of war. ${ }^{141}$ Under natural law, though, this asymmetry was flattened out by the fact that the common law of war applied equally to sovereign

139. 2 John WestLAKe, INTERNATIONAL LAW 2 (1907).

140. See supra note 123 and accompanying text.

141. See generally James Murrow, Order Within Anarchy (2014). 
governments and rebel forces engaged in fighting without the formal backing of a recognized government. ${ }^{142}$ Of course, this is not to suggest that non-state actors such as al-Qaeda are legally or morally equivalent to the type of rebel forces discussed by Vattel or other natural law theorists. There are crucial differences. Rebel forces make claims to political legitimacy with regard to the proper control of the central government; they are, in other words, competitors for the seat of government. In contrast, terrorist organizations are often destabilizing forces seeking to exact revenge on a population or coerce a particular outcome that has nothing to do with gaining control of a government or territory.

The conclusion to be drawn from this evidence is that the original source for the normativity of the laws of war was the broadest possible foundation: the maxims of humanity, moderation, and honor. ${ }^{143}$ These transcendental principles were applied to all parties to an armed conflict - they were "common" to all, even if one of the parties was not a signatory to a treaty or a participant in the project of creating customary norms. The common laws of war were universal principles that were applied universally, even when the conflict was noninternational in nature and the regular machinery of international customs did not formally apply. This is the lost meaning of the phrase that contemporary usage of the term has obfuscated.

\section{The Dual MEANING OF COMMON LAW}

A pertinent example of the transformation of the phrase "common law of war" is the use of the phrase in Winthrop's key treatise on military law. ${ }^{144}$ That treatise includes several references to the common law of war, in each case making clear that the principle applied in the U.S. Civil War; even in Winthrop's treatise, though, the texture and context of the phrase started to evaporate. ${ }^{145}$ It is clear that the phrase was still in use by military lawyers in Win-

142. Again, the fact that natural law applied in this way is not to suggest that it was always followed by rebels, who for many reasons had incentives to ignore the dictates of natural reason.

143. See supra note 123 and accompanying text.

144. See William Winthrop, Military LaW and Precedents 795 (2d ed. 1920).

145. See id. at $795,809$. 
throp's era, in part because of its inclusion in the Lieber Code. ${ }^{146}$ However, if Winthrop's treatise is read without first understanding Lieber's primary use of "common law of war," the phrase starts to generate more confusion than illumination.

For example, Professor John Dehn suggests-by virtue of a close reading of Winthrop's treatise - that a common law of war theory might provide a jurisdictional foundation for prosecuting a domestic war offense before a military tribunal. ${ }^{147}$ Dehn concedes that both Winthrop and Lieber viewed the law of war as a branch of the law of nations, though Dehn argues that this was consistent with punishment of municipal offenses. ${ }^{148}$ Specifically, Dehn argues that Winthrop's recognition of municipal offenses represented the common law development of the law of nations within England-a methodology supported by Winthrop's reputation as the "Blackstone of Military Law." ${ }^{149}$ From this evidence, Dehn catalogues the various offenses that Winthrop identified as violations of the law of war, a result that occurred because "precedent modified the applicable rule" through the "English common law system." 150 This reading is mistaken because it emphasizes the wrong aspect of common law in the concept of the "common law of war." To be fair, this mistake is not Dehn's but rather Winthrop's, who took Lieber's concept of the "common law of war" and gave it a Blackstonian gloss that fundamentally altered the concept as Lieber understood it. ${ }^{151}$

Part of the problem with the task of interpreting the phrase "common law of war" is that the underlying phrase "common law" is inherently ambiguous, even downright mercurial. It includes several related concepts that are intertwined. First, the phrase "common law" refers to a law that is common across different

146. See Lieber Code, supra note 85, art. 13.

147. See John C. Dehn, The Hamdan Case and the Application of a Municipal Offence: The Common Law Origins of 'Murder in Violation of the Law of War,'7 J. INT'L CRIM. Just. 63, 7981 (2009). Dehn's argument regarding the "common law of war" is one part of his multilayered defense of "murder in violation of the law of war" as a crime that can be prosecuted as a municipal offense before a military commission. See id. at 66 . The argument does not address its applicability to the crime of conspiracy. However, the predicate analysis-the existence of a body of municipal law prosecutable before a military commission applying the common law of war-is the same in the conspiracy context.

148. Id. at 75 .

149. Id. at 76 (quoting Hamdan I, 548 U.S. 557, 597 (2006)).

150. Id. at 77 .

151. See Winthrop, supra note 144 , at 773. 
regions, areas, or jurisdictions. As will be described in detail below, the phrase "common law" originally referred to the law that was common to the King's realm, as opposed to local law. ${ }^{152}$ In today's parlance, this commonality of the common law refers to the United States' participation in a shared legal culture that includes other Commonwealth countries, such as Britain, Australia, and Canada, and, in general, all legal jurisdictions that trace their origins back to Anglo-Saxon England. This points to the second element of the phrase "common law," which refers to its historicity. When lawyers talk of the common law, they often refer to the law of England at a particular period of time, as in, for example: "At common law, the courts of law and equity were sharply divided with different procedures, writs, and legal norms." This is an inherently backwardlooking use of the phrase.

Third, the phrase "common law" often refers to "judge-made law," in the sense that lawyers discuss a "common law precedent" or even study "common law decisionmaking." 153 In both instances, the use of the phrase "common law" is designed to highlight the degree to which the legal norm is not embodied in a particular statute. So, for example, certain rules of contract or tort law might be described as common law rules in the sense that judges, in the course of deciding particular cases, articulated and expanded the common law of contract or torts in the absence of statutory regulation. ${ }^{154}$ And, famously, the Erie decision required that federal courts respect that state jurisdictions can each develop their common law in different and unique ways, so that the common law of contracts in Pennsylvania at one point in time might diverge from the common law of contracts in New York State. ${ }^{155}$ This aspect of "common law," especially post-Erie, stands in some tension with the first use of the phrase

152. See infra notes 160-64 and accompanying text.

153. See, e.g., Antonin Scalia, Common-Law Courts in a Civil-Law System: The Role of United States Federal Courts in Interpreting the Constitution and Laws, in A MATTER OF Interpretation: Federal Courts And the LaW 3, 10 (Amy Gutmann ed., 1997). Courts often use the phrase "common law" in this way. See, e.g., Woodman ex rel. Woodman v. Kera LLC, 785 N.W.2d 1, 21 (Mich. 2010). For a discussion of this terminology, see Stephen J. Ware, Originalism, Balanced Legal Realism and Judicial Selection: A Case Study, 22 KaN. J.L. \& PuB. POL'y 165, 170 (2013).

154. See Bradford R. Clark, Federal Common Law: A Structural Reinterpretation, 144 U. PA. L. REv. 1245, 1247 (1996).

155. See Erie R.R. Co. v. Tompkins, 304 U.S. 64, 78 (1938) (“There is no federal general common law.”). 
"common law" as described above, which referred to the law as being common to the whole realm. ${ }^{156}$ One use of the phrase highlights the commonality of the law, while the other use highlights the exact opposite, that is, the variability of the law between jurisdictions (because, as Holmes said, the common law is not some "brooding omnipresence in the sky"). ${ }^{157}$ This shift in viewing the common law as individualized and a fragmentary, centrifugal impulse instead of a centripetal and unifying force cannot be divorced from the growing influence of legal realism that played such an important role in Holmes's thinking, and, ultimately, the Erie decision. ${ }^{158}$

The earliest uses of the phrase "common law," or jus commune, came from canon law. In his history of the laws of England, Hudson dates the concept at least as far back as the Dialogue of the Exchequer, a twelfth-century legal text. ${ }^{159}$ As the phrase developed, it came to refer to the law that was common across the entire realm, as opposed to local practices and legal customs that differed from place to place. ${ }^{160}$ In other words, the point of common law was that there remained fragmentation and pluralism across various localities. ${ }^{161}$ However, there also remained some principles that were truly common and universal, meaning that there were some legal rights or entitlements that did not depend on the particular location where they were asserted. ${ }^{162}$ Those universal principles constituted the common law. The phrase referred to a shared legal culture that was consistent across the realm. ${ }^{163}$

It is precisely this aspect of the phrase "common law" that is picked up by the use of the phrase "common law of war" in both Vattel's philosophy and the Lieber Code. The reason the common

156. See supra note 153 and accompanying text.

157. See S. Pac. Co. v. Jensen, 244 U.S. 205, 222 (1917) (Holmes, J., dissenting) (“The common law is not a brooding omnipresence in the sky but the articulate voice of some sovereign or quasi-sovereign that can be identified.”).

158. But see Jack Goldsmith \& Steven Walt, Erie and the Irrelevance of Legal Positivism, 84 VA. L. REV. 673, 710 (1998) (concluding that scholars are wrong to assume that legal realism determined Erie's outcome because "Erie's holding and what it replaced are consistent with legal realism").

159. 2 John Hudson, The Oxford History of the Laws of England 853 (2012).

160. Id.

161. Id. at 854-55 (indicating that there were "considerable limits to the consistency of law across the realm").

162. See id. at 853.

163. Id. 
law of war applied in all wars, whether international or civil, was that all parties were participants in a shared legal culture-something greater that bound them together. For Vattel, the "common law of war" was not an expression of local exceptionalism; it was, rather, the expression of a common legal culture that applied to everyone equally. Because the international system was built upon natural law, the law was common to the entire "realm," the realm of humanity.

The same notion of commonality undergirds Lieber's use of the term when he refers to the "common law of war." Indeed, Lieber wrote extensively in his other texts about the shared political and legal culture that binds together both parties and enemies in an armed conflict. For example, in his lectures on the law and usages of war, Lieber notes that all nations are part of the same family-the family of "civilization." ${ }^{164}$ Of course, not all natural law theorists were inclined to view the concept of "civilization" broadly. Indeed, some scholars of the natural law era viewed civilization as a religious concept and concluded that the same principles did not generally apply in wars of religion with those outside of the religion. ${ }^{165}$ However, the fact that the concept of civilization was once understood in discriminatory fashion (with racial or religious overtones), as opposed to today's more appropriate universal understanding of the term, does not change the overall interpretation of the concept as a fundamentally transnational regulator. The "common law of war" applied to "humanity" or "civilization" as those latter terms were understood (or misunderstood) in that era. In that sense, the natural inheritor of the common law of war is the "customs and usages of civilized nations," a recognized forerunner of today's more typical reference to customary international law. ${ }^{166}$

Even when nations go to war against each other and seek to defeat each other on the battlefield, they nonetheless retain their common membership in that greater family of civilization. ${ }^{167}$ This

164. Lieber, supra note 109.

165. See, e.g., 1 Henry Wager Halleck, International Law, or Rules Regulating the Intercourse of States in Peace And War ch. XIV, § 7, at 457 (Sherston Baker ed., London,

C. Kegan Paul \& Co. 1878) (1861).

166. The Paquete Habana, 175 U.S. 677, 700 (1900).

167. Lieber notes that the only entities that are not part of the family of civilization are savages; by extension, Lieber concludes that wars of plunder, or genocide, belong to the savage state of man. See Lieber, supra note 109. 
point is no small example of Lieberian political theory; in fact, it provides the normative source for the restrictions and constraints that gain their expression in the laws of war. Lieber believed that the laws of war were binding on all parties to an armed conflict precisely because all parties were members of the same family of civilization. Although local variations might apply depending on location and context, the common core of the law of nations, and by extension the customs of war, remained the same (as long as the participants were all members of a common humanity) because it all flowed from natural law. ${ }^{168}$ Consequently, Lieber's use of the phrase "common law of war" needs to be read within that context. The common law of war was common precisely because the law of war, via the shared element of civilization, was binding on all parties. The use of the phrase "common law of war" directly appealed to the unifying aspect of the common law, not to its more recent usage that emphasizes local divergence and uniqueness and the freedom of judges to decide the law as they see fit.

It is this modern usage the government mistakenly relies upon when it refers to the "common law of war" as the historical practice of the United States regarding prosecutions before military tribunals. ${ }^{169}$ The government's use perverts the concept of the common law by turning it on its head. The government deploys the phrase as a justification for allowing the United States to formulate a purely domestic body of law, based on precedent, which diverges sharply from the practice of international jurisdictions. But this reading of the concept is ahistorical. It ignores the "common law" in the "common law of war." Moreover, it rigidly imposes a very contemporary understanding of the phrase "common law," which is at odds with how the term "common law" was used when the phrase "common law of war" was first used by Vattel and Lieber, by early U.S. courts, and by jurists at the time of the Lincoln trial. ${ }^{170}$ Far from sanctioning U.S. departure from international custom, the phrase "common law of war" in fact does the exact opposite: it reinforces and deepens U.S. compliance with, and participation in, a shared legal culture that is "common" to all. As the following Part

168. See, e.g., 1 Hugo Grotius, On the Rights of War and Peace ch. I, at 17-30 (A.C. Campbell ed. \& trans., 1901) (1625).

169. See supra note 9 and accompanying text.

170. See supra Part IV. 
will demonstrate, the substantive charge of conspiracy is not consistent with the "common law of war" once that phrase's meaning is properly understood.

\section{CONSPIRACY UNDER THE COMMON LAW OF WAR}

Having unearthed a coherent account of the common law of war, the time has now come to apply this interpretation of the term to the government's position in $\mathrm{Al} \mathrm{Bahlul}$ and ask whether the term performs the conceptual work to which the government has assigned it. The government's position is that Bahlul can be prosecuted for conspiracy pursuant to the common law of war because military commissions in the past have prosecuted defendants for conspiracy. ${ }^{171}$ Under this interpretation, the common law of war is a set of purely domestic precedents-prosecution under this common law of war is analogous to the prosecution of "common law crimes" in state courts before criminal law was widely codified in this country. ${ }^{172}$

Commentators have rightly pointed out that interpreting the common law of war in this unilateral fashion would be greatly damaging to the interests of the United States and contrary to the whole purpose of the laws of war. ${ }^{173}$ First, it generates a potential multiplicity of domestic "common laws of war" that are different in each country, which is a bit like saying that there is one version of international law in the United States and another version of international law in Russia or China. ${ }^{174}$ That cannot be the case.

171. See supra notes 8-9 and accompanying text.

172. See Keith S. Alexander, Note, In the Wake of September 11th: The Use of Military Tribunals to Try Terrorists, 78 NotRe DAME L. Rev. 885, 894 (2003) ("Much like prosecutions under traditional English common law crimes, the federal government is prosecuting war criminals in military tribunals using the common law of war.").

173. See Recent Case, Ex Post Facto Clause-Guantánamo Prosecutions-D.C. Circuit Reinterprets Military Commissions Act of 2006 to Allow Retroactive Prosecution of Conspiracy to Commit War Crimes.-Al Bahlul v. United States, 767 F.3d 1 (D.C. Cir. 2014), 128 HaRv. L. REv. 2040, 2047 (2015) (“Additionally, Congress would have recognized that allowing prosecutions under a U.S. common law of war would put American service-members at risk of prosecution under an indeterminate foreign 'common law of war.' The 'unilateralist impulse' that undergirds the government's theory of a U.S. common law of war is yet 'another manifestation of the United States's view that international law should not constrain its ability to wage a global armed conflict against al Qaeda." (footnotes omitted)).

174. Id. ("Therefore, interpreting 'law of war' in $\S 821$ to encompass a U.S. common law of war would defy seventy years of Supreme Court precedent and Congressional intent to further the stability and universality of the international law of war."). 
International law is international law-everywhere. To put the point more sharply, suggesting that the laws of war can be domesticated is like saying that the laws of physics could be different in each country, which is nonsensical. Second, even if this unilateral interpretation were conceptually coherent, it would also be dangerous to the United States. ${ }^{175}$ The whole point of the laws of war is that their reciprocal and universal nature provides stability and predictability to the conflict. ${ }^{176}$ If the United States reserves the right to apply its own domestic common law of war in the Al Bahlul case, it raises the specter of other countries applying their own domestic common law of war against U.S. nationals during a foreign prosecution. This is hardly a satisfactory result for the national interests of the United States.

The historical evidence regarding the phrase "common law of war" deepens this analysis. Only in recent time has the phrase referred to a domestic body of law which is unilateral in nature. ${ }^{177}$ The evidence outlined in the previous parts reveals that the common laws of war were never a unilateral body of law. ${ }^{178}$ In fact, they were precisely the opposite: they were a universal body of law that was common to all parties to the armed conflict. ${ }^{179}$ Indeed, they were arguably more universal than even the international laws of war today, because they stemmed from natural law. ${ }^{180} \mathrm{In}$ fact, the phrase had the opposite meaning of that currently used by lawyers for the United States government. ${ }^{181}$

Consequently, the government's argument regarding Bahlul's conspiracy conviction must fail. The substantive crime of conspiracy is not common at all-something that the government already conceded when it noted that conspiracy is not a violation of international

175. Id. ("This approach would pose serious risks for Americans.... American military prosecutors, judges, and other legal actors could face foreign prosecution 'for the war crime of denial of a fair trial'-an offense recognized under Common Article 3 of the 1949 Geneva Conventions and in the Rome Statute-for prosecuting crimes by military commission that are not recognized as war crimes.").

176. Id. (" $[\mathrm{F}]$ oreign adversaries could assert their own common law of war to try captured American personnel, with tremendous indeterminacy ex ante about what acts are prohibited.").

177. See supra Part II.

178. See supra Parts IV-V.

179. See supra note 141 and accompanying text.

180. See supra Part IV.

181. See supra note 9 and accompanying text. 
law. ${ }^{182}$ The analysis of conspiracy under the common law of war is substantially similar to the analysis of conspiracy under international law, and the result in both cases is the same.

Despite widespread usage of conspiracy language by American lawyers in the run-up to Nuremberg, conspiracy was famously rejected as a substantive offense at Nuremberg itself. ${ }^{183}$ The result was a compromise of sorts: Conspiracy was retained for crimes against peace (what later became aggression), but rejected for all other crimes, including crimes against humanity and war crimes. ${ }^{184}$ Subsequently, conspiracy to commit genocide was included, presumably as an inchoate offense, in the post-World War II Genocide Convention. ${ }^{185}$ The Genocide Convention provision on conspiracy was carried over verbatim into the statutes of the International Criminal Tribunal for the Former Yugoslavia (ICTY) and the International Criminal Tribunal for Rwanda (ICTR), which were passed by the United Nations Security Council in 1993 and 1994, respectively. ${ }^{186}$ However, the drafters of the Rome Statute for the creation of the International Criminal Court (ICC) rejected conspiracy even for genocide and declined to follow the precedents established by the Geneva Convention and the ICTY and ICTR Statutes. ${ }^{187}$ The change of heart is significant. At least part of the shift might be explained by the different negotiation procedures behind these international courts. The ICTY and ICTR were negotiated by the major powers and attached as appendices to Security Council resolutions passed under Chapter VII of the United Nations Charter. ${ }^{188}$ In contrast, the Rome Statute was negotiated by a true international conference, the future state parties to the permanent

182. See supra note 3 and accompanying text.

183. See Patricia M. Wald, Running the Trial of the Century: The Nuremberg Legacy, 27 Cardozo L. ReV. 1559, 1592 (2006).

184. Id. ("In the end no defendant was convicted of conspiracy alone and the conspiracy count was not only restricted to conspiracy to wage aggressive war-and not conspiracy to commit any of the other indictable war crimes or crimes against humanity-but defined on the basis of not one giant but several smaller, more discrete conspiracies.").

185. Convention on the Prevention and Punishment of the Crime of Genocide, Dec. 9, 1948, 78 U.N.T.S. 277; see also Genocide Convention Implementation Act of 1987, Pub. L. No. 100606 (codified at 18 U.S.C. $\S \S 1091-1093$ (2012)).

186. S.C. Res. 827 (May 25, 1993); S.C. Res. 955 (Nov. 8, 1994) [hereinafter ICTR Statute]. 187. Rome Statute of the International Criminal Court, July 17, 1998, art. 6, 2187 U.N.T.S 90 [hereinafter Rome Statute].

188. See supra note 187 and accompanying text. 
court. ${ }^{189}$ In that wider forum, conspiracy as a substantive offense had even less support-even for the crime of conspiracy to commit genocide.

Digesting all of this information, the most that can be said of conspiracy as a substantive offense is that it remains an internationally viable doctrine in isolated pockets of jurisprudence for core crimes that are considered especially dangerous for the international community in two very discrete circumstances: genocide and aggression. However, even that conclusion is somewhat overstated, given the Rome Statute's categorical rejection of conspiracy and the lack of any modern precedent for conspiracy to commit aggression. ${ }^{190}$ George Fletcher was certainly right when he declared that conspiracy to commit genocide was "the afterglow of a dying concept." 191 The most that can be said is that conspiracy to commit genocide was a viable inchoate offense at the ICTR, where genocide is regarded as a particularly virulent danger that requires extra penal tools-including inchoate offenses-affording authorities the opportunity to intervene in burgeoning criminal endeavors. ${ }^{192}$ This rationale helps explain both conspiracy to commit genocide as well as direct and public incitement to commit genocide. ${ }^{193}$

The United States continues to use conspiracy as an inchoate offense to prosecute terrorists. ${ }^{194}$ Also, the federal government often uses conspiracy in tandem with other inchoate offenses, such as attempt and material support for terrorism, with the result being double inchoate offenses such as attempt or conspiracy to provide material support for terrorism. ${ }^{195}$ Although conspiracy is certainly used in some other jurisdictions as well, in terrorism and other domestic law offenses it does not form part of the universal grammar

189. See Rome Statute, supra note 187 , art. 1.

190. See id. art. 6.

191. Amicus Curiae Brief for Specialists in Conspiracy and International Law Petitioner at 12, Hamdan I, 548 U.S. 557 (2006) (No. 05-184), 2006 WL 53979.

192. See ICTR Statute, supra note 186.

193. The ICTR concluded, arguably in dicta, that incitement to commit genocide could be prosecuted in an inchoate context. See Prosecutor v. Akayesu, Case No. ICTR-96-4-T, Judgement, ๆ 561 (Sept. 2, 1998).

194. For a discussion of some of these prosecutions, see WAdIE E. SAID, Crimes of TERror 107-09 (2015).

195. For examples, see United States v. Ahmed, 107 F. Supp. 3d 1002, 1005 (D. Minn. 2015); United States v. Ahmed, 94 F. Supp. 3d 394, 406 (E.D.N.Y. 2015), reh'g denied, No. 12 CR-661 (SLT) (S-2), 2015 WL 1636827 (E.D.N.Y. Apr. 10, 2015). 
of criminal law. Plenty of domestic jurisdictions exclude conspiracy from their domestic penal law, preferring instead to rely on other concepts and doctrines. The hesitation felt by civil law jurists at Nuremberg certainly lingers to this day.

\section{CONCLUSION}

Whether conspiracy forms a part of the common law of war depends entirely on what, exactly, the "common law of war" means. If the common law of war is a pure creature of domestic law, there might be some rationale for lending credence to the government's legal theory as advocated in Al Bahlul. However, if the common law of war is a body of law that is truly "common"-as outlined in this Article - then conspiracy has no place in it. Indeed, even Justice Thomas, who voted in favor of the commissions' jurisdiction over the crime of conspiracy, should support this conclusion since he has already stated that the common law of war derives from the common usages of civilized nations. ${ }^{196}$ Conspiracy is an expression of U.S. legal exceptionalism, which may have its place in Article III courts. But military commissions apply the law of war, which can either be described as the international law of war or the common law of war; either way, conspiracy is not a part of it. laws and usages of war as understood and practiced by the civilized nations of the world," a citation that implicitly recognizes the natural law origins of the term. Hamdan I, 548 U.S. 557, 689 (2006) (Thomas, J., dissenting) (quoting Military Comm'ns, 11 Op. Atty. Gen. 297, $310(1865))$. 
